\title{
Effects of Extraction Time on the Quality Characteristics of Purple Corn Cob Extract
}

\author{
Ji-yun Jeong • Hee-Jin Park • Byung-Hee Kim "Sung-Soo Kim*

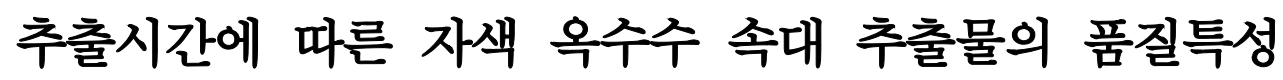

정지윤 · 박희진 · 김병희 · 김성수*

Received: 1 June 2015 / Accepted: 7 September 2015 / Published Online: 31 December 2015

(C) The Korean Society for Applied Biological Chemistry 2015

\begin{abstract}
In this study, the quality characteristics of purple corn cob extract (PCCE) by extraction time were examined. The cob of purple corn, which is mainly cultivated in the Andes region of South America, contains more anthocyanin than the corresponding purple corn seeds. The aim of this study was to determine the optimal conditions for the preparation of water extracts from purple corn cob. PCCE had a soluble solid content of $0.6^{\circ}$ Brix. The Hunter lightness $\left(\mathrm{L}^{*}\right)$, redness $\left(\mathrm{a}^{*}\right)$, yellowness $\left(\mathrm{b}^{*}\right)$ values of the PCCE were 31.0, 38.4, and 9.0, respectively. The PCCE contained $24.64 \mathrm{mg} / \mathrm{g}$ of cyanidin, $0.35 \mathrm{mg} / \mathrm{g}$ of pelargonidin, and $17.42 \mathrm{mg} / \mathrm{g}$ peonidin, and showed greater antioxidant activity than the other extracts. Therefore, the optimal extracting conditions for preparing PCCE were a temperature of $30^{\circ} \mathrm{C}$ and an extraction time of $24 \mathrm{~h}$.
\end{abstract}

Keywords anthocyanidin $\cdot$ antioxidant $\cdot \mathrm{cob} \cdot$ purple corn

J.-Y. Jeong $\cdot$ H.-J. Park · S.-S. Kim

Department of Food Processing Technology, Division of Strategic Food Research, Seongnam 463-746, Republic of Korea

B.-H. Kim

Department of Food Science and Technology, Chung-ang University, Anseong 456-756, Republic of Korea

*Corresponding author (S.-S. Kim: sung@kfri.re.kr)

This is an Open Access article distributed under the terms of the Creative Commons Attribution Non-Commercial License (http://creativecommons. org/licenses/by-nc/3.0/) which permits unrestricted non-commercial use, distribution, and reproduction in any medium, provided the original work is properly cited.

\section{서 론}

옥수수(Zea mays L.)는 세계 3대 작물로서 매우 중요한 위치를 차지하고 있다( $\operatorname{Kim}$ 등, 2013). 옥수수의 항당뇨(Niwa 등, 2003), 항균(Mellon과 Moreau, 2004), 항산화, 항노화(Choi 등, 2007), 항고혈압, 항암 기능 외에 폴리페놀, 식물성스테롤, 토코 페롤 유도체, 카로티노이드 등의 기능성 물질에 대한 연구가 진 행되면서 식량 외에도 건강기능식품, 화장품 및 의약품 소재 분 야에서 널리 사용되고 있다(Plate와 Gallaher, 2005). 세계적으로 옥수수는 종류가 다양하며 흰색, 노란색, 적색, 자색, 갈색, 녹 색과 남색으로 구분한다 $(\mathrm{Li}, 2007)$. 그 중 자색 옥수수 $(\mathrm{Zea}$ mays L.)는 남아메리카 페루 안데스 산맥에서 자생하는 옥수수 의 한 품종으로 안토시아닌 성분이 풍부하며 이로 인해 잎맥, 종식 및 속대가 진한 보라색을 띠고 있다. 안토시아닌은 포도, 베리류, 적양배추, 사과, 순무 등에 주로 존재하며 과실, 줄기, 잎, 뿌리 등 식품체의 각 부위에 폭넓게 분포되어 있는 수용성 색소이다(Coe 등, 1988; Henry, 1992; Dey와 Harborne, 1993). 안토시아닌의 주요 기능은 활성산소종(reactive oxygen species) 에서 야기되는 산화적 스트레스(oxidative stress)에 의한 신경세 포의 손상을 보호기능을 한다(Smith 등, 2000; Heo와 Lee, 2005). 이 외에 안토시아닌은 항산화활성(Moyer 등, 2002; Chang 등, 2008), 지질대사 조절 기능(Tusba 등, 2003), 시력 및 난소 기능 향상 $(\mathrm{Kim}$ 등, 2001) 등 다양한 생리활성을 나타 낸다. 이에 따라 안토시아닌 색소가 포함된 자색 옥수수를 이 용하여 다양한 연구들이 진행되고 있다. 일본의 초지연구소 (National Intstitute of Licestock and Grassland Science)에서는 최근 고함유 안토시아닌 품종인 Choko C922를 개발하여 사일 리지(Silage)로 이용하여 사양시험에 대한 연구를 진행하고 있 으며(Kenji 등, 2009), 멕시코에서는 자색 옥수수 유전자원에 대 한 색소 연구가 진행되고 있다(Lopez-Martinez 등, 2009). 그러 나 Meiers 등(2001)은 외음암에 대한 항암 능력이 안토시아닌 보다 안토시아니딘에 의해 우선적으로 일어난다고 하였으며 안 
토시아닌, 안토시아니딘 및 카테킨의 지방의 과산화 저해능을 비교한 연구(Seeram과 Nair, 2002) 의하면 안토시아니딘의 철이 온 환원력이 안토시아닌보다 높다고 보고되었다. 이는 안토시아 니딘의 하이드록실기가 갈로일 그룹이나 당으로 대체되어 안토 시아닌이 될 경우 안정된 분자였던 $\mathrm{B}$ ring이 뒤틀리면서 평면 구조를 잃고 결합 또한 약해짐에 따라 나타나는 결과이다. 즉 안토시아니딘이 안토시아닌에 비해 높은 항산화 기능을 하는 것 으로 사료된다. 안토시아니딘은 안토시아닌과 달리 당이 결합되 어 있지 않은 구조로, 채소 및 과실류에 가장 많이 존재하는 안 토시아니딘은 cyanidin이며, 이외에 delphinidin, pelargonidin, peonidin, petunidin 및 malvidin 등이 존재한다(Mazza와 Miniati, 1993). 안토시아니딘은 세포나 세포막의 지방 성분이 과산화되 는 것을 방지하는 역할을 한다고 알려져 있다(Tsuda 등, 1994; Tsuda 등, 1996). 또한 Malaj 등(2013)에 따르면 안토시아니딘 은 색소성분 및 질병 예방 효과가 입증되어 인공색소를 대체 가능하다는 장점이 있으며 더 나아가 안토시아니딘과 다른 무 색의 분자들 사이의 공액색소화에 의해 색상의 강도가 더 강해 질 수 있다고 한다. 그러나 기존의 연구들은 자색 옥수수의 안 토시아닌에 초점을 맞추고 있어 안토시아니딘에 대한 연구는 미 비한 실정이다. Yang과 Zhai(2010)는 자색 옥수수 종실(55.8 $\mathrm{mg} / 100 \mathrm{~g})$ 보다 속대 $(92.3 \mathrm{mg} / 100 \mathrm{~g})$ 의 총 안토시아닌 함량이 높 다고 보고하였으며, $\operatorname{Li}(2007)$ 는 자색 옥수수 부위별 cyanidin 3O-glucoside 생산량을 확인한 결과 부산물 중 속대 $(1298.29 \mathrm{mg} /$ $\mathrm{g}$ )에서의 생산량이 잎, 줄기, 수술, 겉껍질 $(60.41-1240.93 \mathrm{mg} / \mathrm{g}$ ) 보다 높다고 하였다. 자색 옥수수의 부산물은 비가식 부위로 이 용도가 낮으나 수량이 많아서 이용도를 높일 경우 새로운 부가 가치를 창출할 수 있을 것으로 예상된다(Kim 등, 2013). 따라 서 본 연구는 추출 시간에 따른 자색 옥수수 속대 추출물의 안 토시아니딘 함량과 항산화활성을 확인하고 이를 바탕으로 최적 추출조건을 선정하기 위해 실시하였다.

\section{재료 및 방법}

실험재료. 본 실험의 재료는 페루에서 재배되어 건조된 자색 옥 수수 속대로 일반성분 분석 결과는 Table 1과 같다. 건조된 자 색 옥수수 속대 $100 \mathrm{~g}$ 기준, 열량 $340.5 \mathrm{kcal}$, 수분 $13.57 \mathrm{~g}$, 지 방 $0.38 \mathrm{~g}$, 단백질 $1.80 \mathrm{~g}$, 회분 $1.77 \mathrm{~g}$ 및 탄수화물 $82.48 \mathrm{~g}$ 인 것을 (주)서한냉동(Seoul, Korea)으로 부터 공급받아 사용하였다. 자색 옥수수 속대 추출물 제조. Jing과 Giusti(2007)의 연구에 따르면 정제수, 산성화된 정제수 및 산성화된 에탄올을 이용하 여 자색 옥수수의 색소 성분을 추출한 결과 정제수로 추출하였 을 때 안토시아닌의 추출량이 $0.68 \mathrm{~g} / 100 \mathrm{~g}$ dry weight로 산성화 된 정제수 $(0.60 \mathrm{~g} / 100 \mathrm{~g}$ dry weight) 및 산성화된 에탄올 $(0.14 \mathrm{~g} /$ $100 \mathrm{~g}$ dry weight)에 비하여 안토시아닌의 추출이 잘 일어난다 고 하였다. 따라서 자색 옥수수 속대 추출물은 건조된 자색 옥 수수에서 분리한 속대에 10 배의 정제수를 가하여 추출하였다. 추출 기기로는 shake incubator (MR-R505, Mega Science, Korea) 를 사용하였으며, $30^{\circ} \mathrm{C}$ 에서 $4,8,12,16,20,24,32$ 및 40 시 간 추출하였다. 추출물은 Whatman filter paper No. 4로 여과 한 후 $4^{\circ} \mathrm{C}$ 에서 보관하였다. 자색 옥수수 속대 추출물은 3 회 반 복하여 품질 평가를 실시하였다.

가용성 고형물 함량. 추출 시간에 따른 자색 옥수수 속대 추출 물의 가용성 고형물 함량은 refractometer (PR-201a, Atago, Japan)
를 이용하여 ${ }^{\mathrm{o}} \mathrm{Brix}$ 의 단위로 측정하였다.

색도. 자색 옥수수 속대 추출물의 색도는 원통형 용기 $(1 \times 4 \mathrm{~cm}$ i.d.)에 담아 색차계(CR-200, Minolta, Japan)를 사용하여 Hunter value로 측정하였다. 이 때의 표준색은 $\mathrm{L}$ 값이 94.39 , a값이 -0.31 , $\mathrm{b}$ 값이 +0.31 인 calibration plate를 표준으로 하였다.

안토시아니딘 함량. 자색 옥수수 속대 추출물의 안토시아니딘 함량 분석은 Jing과 Giusti(2007)의 방법에 준하여 실시하였다. 표준물질로는 당이 결합되지 않은 cyanidin, pelargonidin 및 pionidin (Chromadex, Irvine, USA)를 사용하였다. 고성능 액체 크로마토그래피(high performance liquid chromatography 시스 템(Chrompass Data System, JASCO, Japan)은 auto sampler (AS-2051 plus, JASCO), Chrompass software (ver. 1.8.6.1, JASCO) 및 photodiode array detector (MD-2010, JASCO)를 이용하여 $520 \mathrm{~nm}$ 에서 측정하였다. 컬럼은 $5 \mu \mathrm{m}$ Symmetry C18 column $\left(250 \times 4.6 \mathrm{~mm}\right.$, SunFire ${ }^{\mathrm{TM}}$, Waters Corp, USA)를 사용 하였으며, 컬럼의 온도는 $30^{\circ} \mathrm{C}$ 로 유지하였다. Injection volume 은 $50 \mu \mathrm{L}$ 이었으며, 이동상 $\mathrm{A}$ 는 water/acetic acid/acetonitrile/ phosphoric acid (84:10:5:1, v/v/v/v), 이동상 $\mathrm{B}$ 는 $100 \%$ acetonitrile 을 이용하였다. 이동상은 $0-5$ 분에서는 $0 \% \mathrm{~B}$ 를, 5-45분에서는 $0-30 \% \mathrm{~B}$ 를, 45-55분에서는 30-0\% B로 하여 분석하였다.

항산화활성. DPPH (1,1-dephenyl-2-picrylhydrazyl) radical 소거 능은 Blois(1958)의 방법을 변형하여 측정하였다. 시료 $0.1 \mathrm{~mL}$ 에 $0.1 \mathrm{mM} \mathrm{DPPH}$ 용액 $3 \mathrm{~mL}$ 를 혼합하여 $30^{\circ} \mathrm{C}$ 의 암소에서 30 분간 방치한 후 $517 \mathrm{~nm}$ 에서 흡광도를 측정하였다. ABTS (2,2'azinobis-3-ethyl-benzothiazoline-6-sulfonic acid) 라디칼 소거능 활성은 Pavel 등(2006)의 방법에 준하여 사용하였다. $7.0 \mathrm{mM}$ $\mathrm{ABTS}$ 와 $4.95 \mathrm{mM}$ potassium persulfate를 혼합하여 암소에서 15 시간 방치하였다. $731 \mathrm{~nm}$ 에서 흡광도가 $1.0-1.5$ 가 되도록 phosphate buffer로 희석하였다. 희석된 $\mathrm{ABTS}$ 용액 $3.9 \mathrm{~mL}$ 과 시료 $0.1 \mathrm{~mL}$ 를 혼합하여 10 분간 $37^{\circ} \mathrm{C}$ 의 암소에서 정치한 후 $731 \mathrm{~nm}$ 에서 흡광도를 측정하였다. 철 이온 환원력 분석은 Benzie 와 Strain(1996)의 방법을 수정하여 사용하였다. 각 시료 $0.2 \mathrm{~mL}$ 에 FRAP 용액(300 mM sodium acetate buffer: $10 \mathrm{mM}$ TPTZ: $\left.20 \mathrm{mM} \mathrm{FeCl}{ }_{3} \cdot 6 \mathrm{H}_{2} \mathrm{O}, 10: 1: 1, \mathrm{v} / \mathrm{v} / \mathrm{v}\right) 3.8 \mathrm{~mL}$ 을 첨가하여 $30^{\circ} \mathrm{C}$ 에 서 30 분간 방치하였으며, $593 \mathrm{~nm}$ 에서 흡광도를 측정하였다.

통계분석. 통계분석은 Statistical Analysis System program version 9.0 (SAS Institute Inc., USA)를 사용하여 실시하였다. 본 실험에서 얻어진 결과는 일원배치 분산분석 (one-way $\mathrm{ANOVA}$ )과 사후검정으로 Duncan의 다중검정방법을 이용하여 $5 \%$ 유의수준에서 실시하였다.

\section{결과 및 고찰}

가용성 고형물 함량. 추출 시간에 따른 옥수수 속대 추출물의 가용성 고형물 함량 변화를 Fig. 1에 나타내었다. 추출 시간에 따른 가용성 고형물의 함량은 $0.3-0.6^{\circ} \mathrm{Brix}$ 범위로 추출 시간이 경과할수록 가용성 고형물의 함량이 높아지는 경향을 보였다. 특히 24시간 추출하여 제조한 추출물의 가용성 고형물 함량은 4-20시간 추출하여 얻은 추출물의 가용성 고형물 함량에 비해 유의적으로 $(p<0.05)$ 높았으며 추출 시간 24 시간 이후에는 추출 물의 가용성 고형물 함량에 유의적인 차이가 없었다. 따라서 자 색 옥수수 속대는 24 시간 추출하였을 때 가용성 고형물을 최대 로 얻을 수 있는 것으로 판단되었다. 


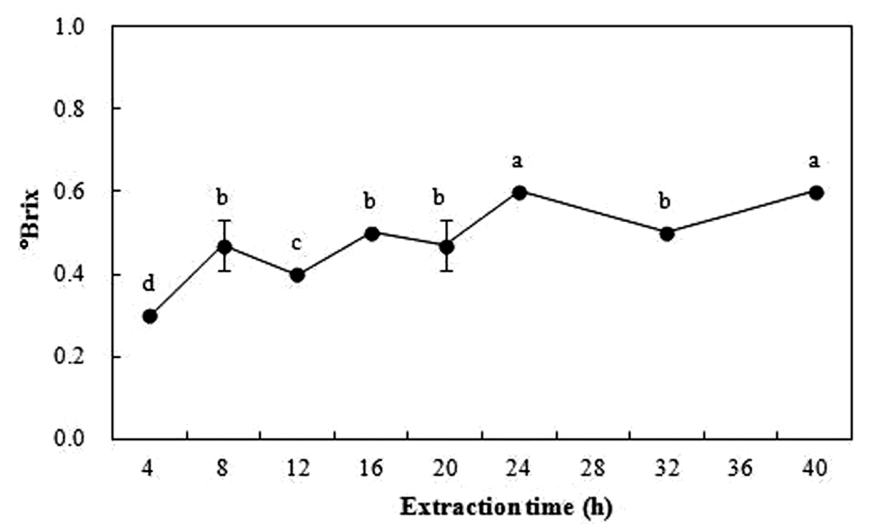

Fig. 1 Changes in soluble solid content of purple corn cob extract as a function of extraction time. Means with different letters (a-d) are significantly different $(p<0.05)$.

색도. Fig. 2는 추출 시간에 따른 옥수수 속대 추출물의 색도 변화를 보여주고 있다. 4시간 추출물에서 명도(L)는 40.6으로 나타났으며, 추출 시간이 길어짐에 따라 30.8 까지 감소하여 점 점 어두워지는 경향을 나타내었다. 적색도를 나타내는 $\mathrm{a}$ 값은 4 시간 추출물에서 27.2로 명도와 반대로 추출 시간이 경과함에 따라 38.7까지 증가하였다. 황색도(b)는 4-16시간 추출물에서 15.7-16.6 범위로 유의적으로 차이를 보이지 않았으나, 그 이후 8.6 까지 감소하여 황색도가 낮아지는 경향을 보였다. 이는 추출 시간이 길어질수록 자색 옥수수 속대에서 추출되는 안토시아닌 이 증가하여 적색 및 청색이 짙어지는데 기인한 것으로 판단되 었다. Lee 등(2008)은 흑미의 추출 시간이 경과할수록 명도가 감소하고 적색도는 증가하였다고 보고한 바 있으며 Montes 등
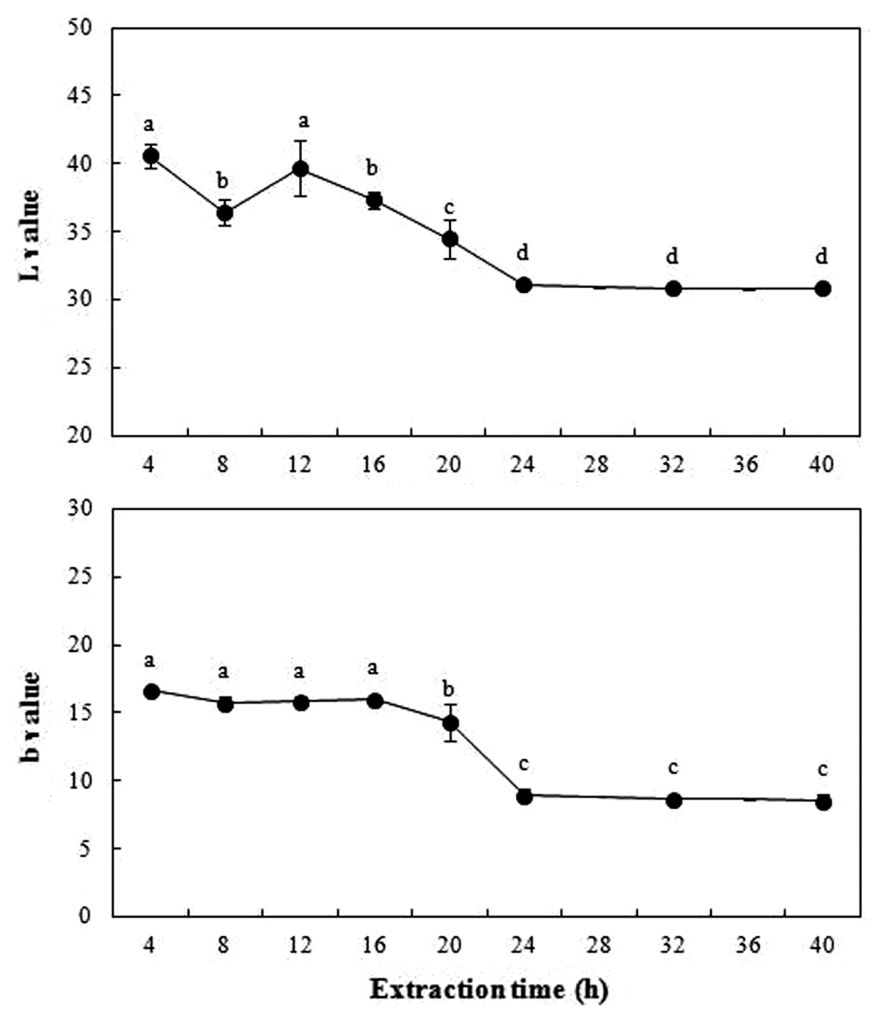

(2005)은 juboticaba fruit에서 추출된 안토시아닌의 양과 색도에 상관관계가 있다고 하였다. 또한 Yang 등(2009)의 연구에서도 명도가 높게 나타나는 것은 안토시아닌의 추출량이 적음을 나 타낸다고 보고하였다. 자색 옥수수 속대의 경우 24 시간 추출하 였을 때 명도와 황색도가 낮고 적색도가 높게 나타났으며 추출 24 시간을 경과함에 따라 색도의 차이가 나타나지 않았으므로 자 색 옥수수 속대의 추출 시간은 24 시간이 적합할 것으로 판단되 었다.

안토시아니딘 함량. 추출 시간에 따른 자색 옥수수 속대 추출 물의 cyanidin, pelargonidin, peonidin의 함량 변화를 Fig. 3에 나타내었다. 추출 시간에 따른 안토시아니딘 함량은 색도와 유 사한 경향을 나타내었다. Cyanidin 함량은 자색 옥수수 속대 추 출 4-24시간에서 추출 시간이 길어짐에 따라 $2.03-24.64 \mathrm{mg} / \mathrm{g}$ 의 범위로 증가하는 경향을 보였으며, 추출 시간 24 시간일 때 cyanidin의 함량은 $24.64 \mathrm{mg} / \mathrm{g}$ 으로 유의적으로 가장 높았다 $(p$ $<0.05$ ). 추출물의 pelargonidin 함량 또한 cyanidin의 함량과 유 사한 경향으로 나타났다. 4-24시간 추출한 자색 옥수수 속대 추출물의 pelargonidin 함량은 $0.35 \mathrm{mg} / \mathrm{g}$ 으로 가장 높았으며, 24 시간 이후 추출물에 대해서는 pelargonidin 함량이 g당 0.19 $0.25 \mathrm{mg}$ 으로 유의적으로 낮게 나타났다 $(p<0.05)$. 이를 통해 24 시간 추출물에서 pelargonidin의 함량이 유의적으로 높은 것을 확인하였다 $(p<0.05)$. peonidin의 함량은 4-20시간 추출물에 대 하여 $1.79-6.92 \mathrm{mg} / \mathrm{g}$ 농도로 나타나 추출시간이 증가함에 따라 peonidin 함량이 증가하였다. 24시간 추출 했을 때, peonidin은 4-20시간 추출물과 유의적 차이를 보이며 $17.42 \mathrm{mg} / \mathrm{g}$ 까지 증가 하였다 $(p<0.05)$. 32시간 추출물의 peonidin 함량 $(11.33 \mathrm{mg} / \mathrm{g})$ 은 24 시간 추출물에 비해 감소하였으나 40 시간 추출물의 peonidin 함량은 $15.27 \mathrm{mg} / \mathrm{g}$ 으로 24시간 추출물과 유의차를 보이지 않았 다. 이에 따라 자색 옥수수 속대 추출물의 안토시아니딘 총량

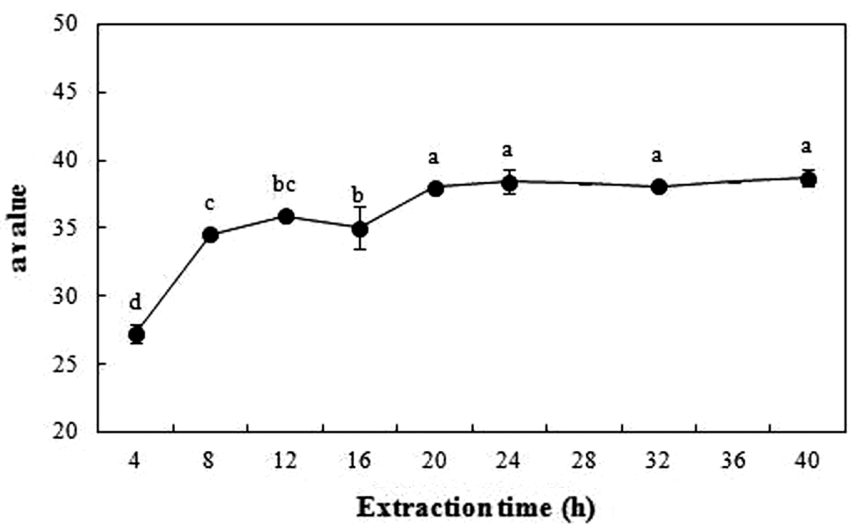

Fig. 2 Changes in hunter color scale value of purple corn cob extract as a function of extraction time. Means with different letters (a-d) are significantly different $(p<0.05)$. 

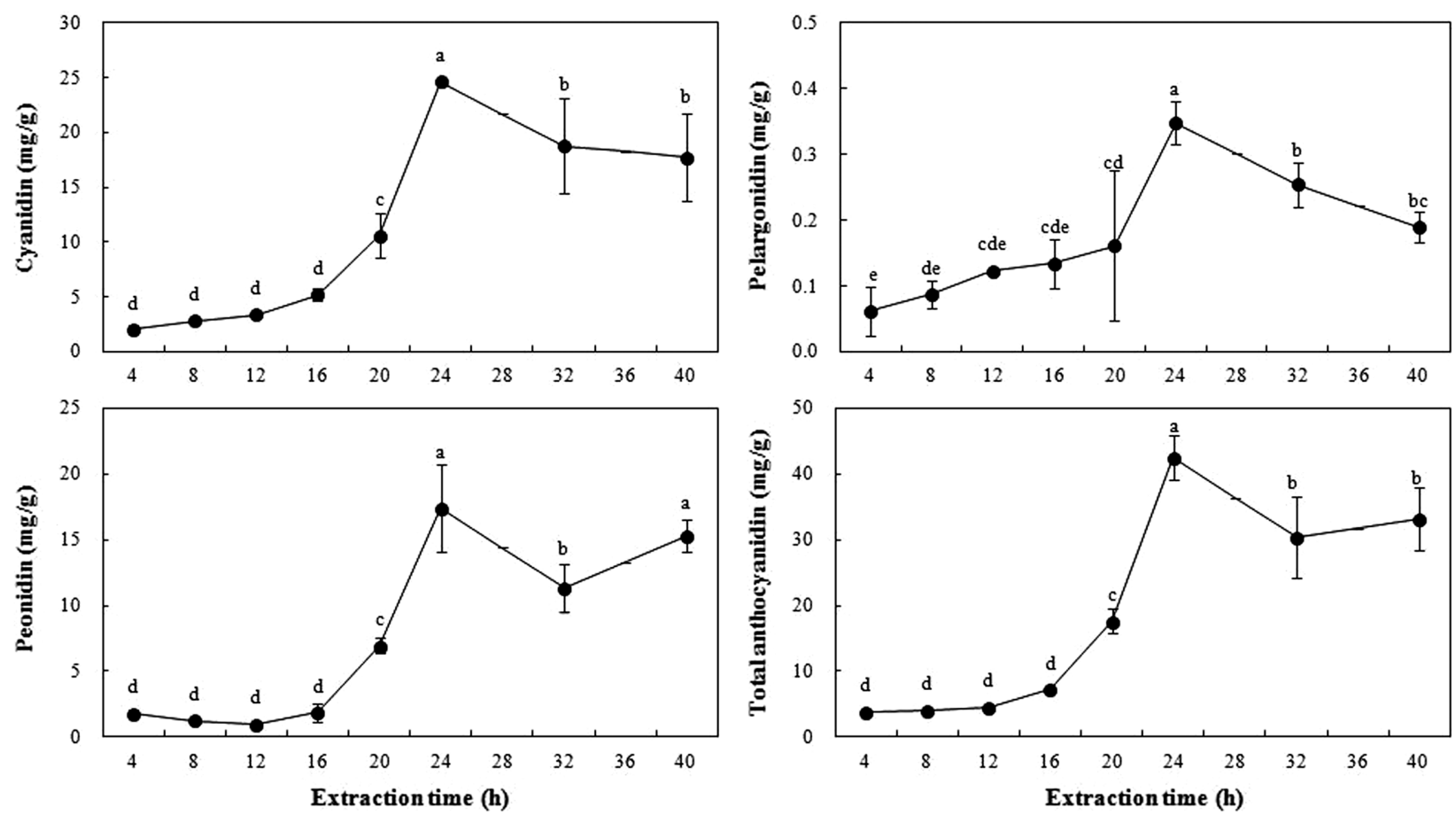

Fig. 3 Changes in cyaniding, pelargonidin, peonidin and total anthocyanin of purple corn cob extract as a function of extraction time. Means with different letters $(\mathrm{a}-\mathrm{d})$ are significantly different $(p<0.05)$.

또한 추출 24 시간까지 점차 증가하다가 24 시간을 초과하여 추 출함에 따라 안토시아니딘 함량이 유의적으로 감소하였다 $(p$ $<0.05)$. Choung 등(2008)의 보고에 따르면 검종콩 종피의 추출 시간이 3 시간에서 12 시간까지 증대됨에 따라 총 안토시아닌 함 량이 $6.38 \mathrm{mg} / \mathrm{g}$ 에서 $8.12 \mathrm{mg} / \mathrm{g}$ 으로 유의적으로 증가하였으며 24 시간 이상 추출할 경우 총 안토시아닌 함량은 $6.77 \mathrm{mg} / \mathrm{g}$ 으로 점 차 감소되는 양상을 확인하였는데 이는 색소를 추출하는 시간 이 지속될 때 소규모의 구조적 파괴가 수반됨에 따라 나타나는 결과라고 하였다. 따라서 안토시아니딘을 최대로 얻을 수 있는 최적 추출 시간은 24시간으로 판단되었으며 이 때 추출물의 cyanidin, pelargonidin, peonidin 함량 및 안토시아니딘 총량은 자색 옥수수 속대 $\mathrm{g}$ 당 각각 $24.64,0.35,17.42$ 및 $42.41 \mathrm{mg}$ 이 었다.

항산화활성. 자색 옥수수 속대 추출물의 DPPH 라디칼 소거활 성을 측정한 결과를 Fig. 4에 나타내었다. 4시간 추출물의 $\mathrm{DPPH}$ 라디칼 소거활성은 $61.0 \%$ 로 나타났으며, 추출 시간이 길 어짐에 따라 증가하는 경향을 보였다. 라디칼의 소거활성은 24 시간 추출했을 때 $82.3 \%$ 로 유의적으로 가장 높게 나타났으며 $(p<0.05), 24$ 시간 이상 추출한 추출물의 라디칼 소거능은 각각 82.3 및 $81.9 \%$ 로 24 시간 추출물과 차이를 보이지 않았다. $\mathrm{TEAC}$ 실험 결과 $\mathrm{DPPH}$ 결과와 유사한 경향을 보였다. 4시간 추출물에서 소거활성은 $61.5 \%$ 로 나타났으며 이후 24 시간까지 의 추출물은 추출 시간의 경과 $(8,12,16,20$ 및 24 시간)에 따 라 소거활성은 $66.2,66.9,68.6,71.6$ 및 $83.5 \%$ 로 증가하는 경 향을 보였다. 24시간 추출물의 소거 활성이 유의적으로 가장 높 았으며 $(p<0.05), 24$ 시간 이후 추출물에 대해서는 소거 활성이 일정하게 유지되었다. FRAP을 통한 자색 옥수수 속대 추출물 의 흡광도 측정한 결과, 4-24시간 추출물의 흡광도는 $0.3-0.5$
범위로 추출 시간이 길어질수록 흡광도는 증가하여 24 시간 흡 광도가 가장 높게 나타났다 $(p<0.05) .24$ 시간 이후 추출물 $(32$ 및 40 시간)은 24 시간 추출물과 유의차는 나타나지 않았으나 24 시 간 추출물에 비해 흡광도가 감소하였다. 안토시아니딘이 당과 결합할 경우 안토시아닌으로 존재하는데 Jakobek 등(2007)은 안 토시아닌 함량이 항산화능과 밀접한 관계가 있다고 보고하였으 며 안토시아닌 함량 또는 추출물과 라디칼 소거능의 직접적인 관계는 직선형 회귀로 분석된다고 하였다(River-Prez 등, 2008; Lachman 등, 2009; Yang과 Zhai, 2010). Ichikawa 등(2001)은 cyanidin이 superoxide 라디칼 소거능에 기여하는 유효성분이므 로 cyanidin의 함량이 항산화능에 영향을 미칠 것이라는 결과와 일치하였다. 즉 항산화능이 추출 24 시간까지 점차 증가하다가 24 시간 이후 유의차가 없는 것은 자색 옥수수 속대를 24 시간까 지 추출하는 동안 안토시아닌의 함량의 변화와 관계가 있는 것 으로 판단되었다. 따라서 항산화능이 높은 자색 옥수수 속대 추 출물을 얻기 위해서 $30^{\circ} \mathrm{C}$ 에서 24 시간 추출하는 것이 적합할 것 으로 보인다.

\section{초 록}

본 연구는 자색 옥수수 속대의 가공식품 및 기능성 식품의 원 료로서 이용 가능성을 평가하기 위하여 자색 옥수수의 속대 추 출 시간을 달리하여 추출물을 제조하고 품질특성을 조사하였다. 추출 시간에 따른 자색 옥수수 속대 추출물 분석 결과, 자색 옥 수수 속대를 $30^{\circ} \mathrm{C}$ 에 24 시간까지 추출하면서 시간의 경과에 따 라 가용성 고형물 및 적색도의 증가와 명도 및 황색도의 감소 가 나타났다. 그러나 추출 시간이 24시간을 경과함에 따라 품 


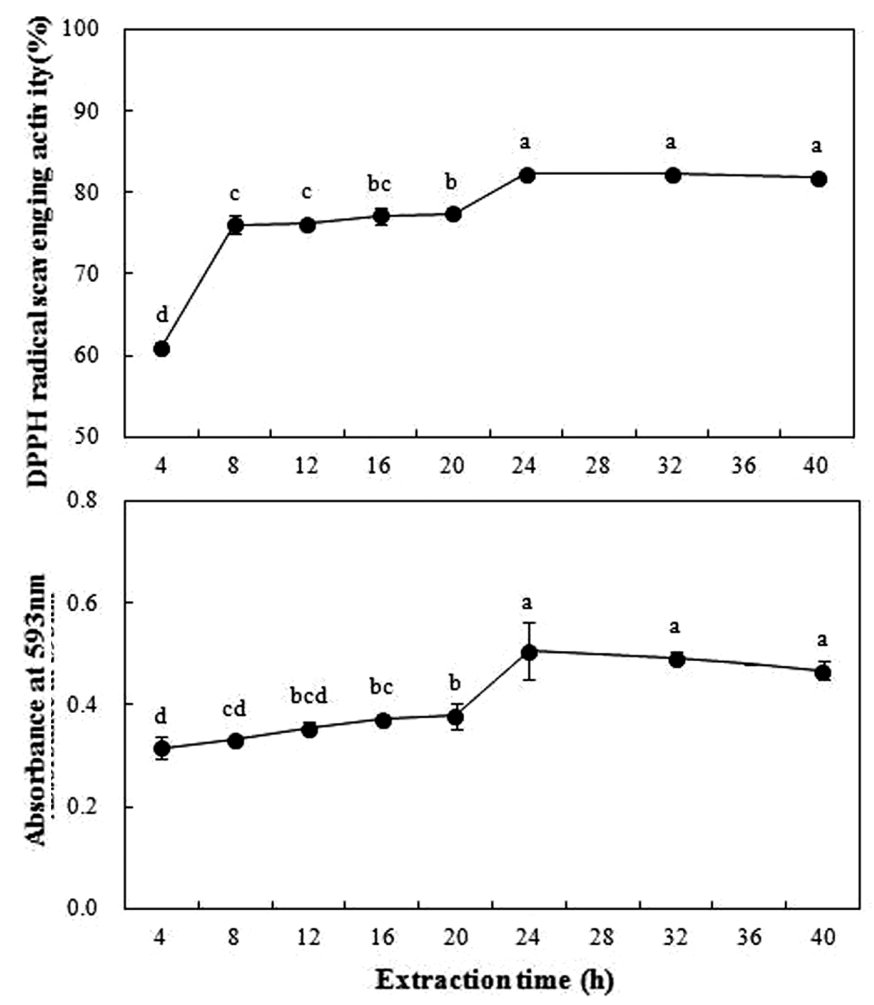

질 특성은 24시간 추출물과 유사하거나 가용성 고형물 및 적색 도가 감소하였으며 명도 및 황색도가 증가하였다. 특히 항산화 활성은 추출 24시간까지 유의적으로 증가했으며 24시간 이후 유의적인 차이는 나타나지 않았다. 즉, 자색 옥수수 속대는 가 용성 고형물 함량, 안토시아니딘 함량, 항산화활성이 24시간에 서 유의적으로 높았기 때문에 자색 옥수수 속대의 최적 추출 시간은 24시간으로 판단되었다.

Keywords 속대 · 안토시아니딘 · 자색 옥수수 · 항산

\section{References}

Benzie IF and Strain JJ (1996) The ferric reducing ability of plasma (FRAP) as a measure of "antioxidant power": The FRAP assay. J Anal Biochem 239, 706.

Blois MS (1958) Antioxidant determinations by the use or a stable free radical. Nature 181, 1990-2100.

Chang HJ, Choi EH, and Chun HS (2008) Quatitative strcture-activity relationship (QSAR) of antioxidative anthocyanins and their glycosides. Food Sci Biotechnol 17, 501-7.

Choi SW, Lee SK, Kim EO, Oh JH, Yoon KS, Parris N et al. (2007) Antioxidant and antimelanogenic activities of polyamine conjugates from corn bran and related hydroxycinnamic acids. J Agric Food Chem 23, 1090-2.

Choung MG, Hwang YS, Lee HJ, Choi SSN, Lim JD, Kang ST et al. (2008) Optimal extraction condition of anthocyanins in soybean (Glycine max) with black seed coats. Kor J Crop Sci 53, 110-7.

Coe Jr. EH, Neuffer MG, and Hoisington DA (1988) The genetics of corn. In Corn and Corn Improvement, Spague GF and Dudley JW (3rd ed.), pp. 83-258. American Society of Agronomy, USA.

Dey PM and Harborne JB (1993) In Plant phenolics methods in plant biochemistry, (2nd ed.). Academic Press Ltd, UK.

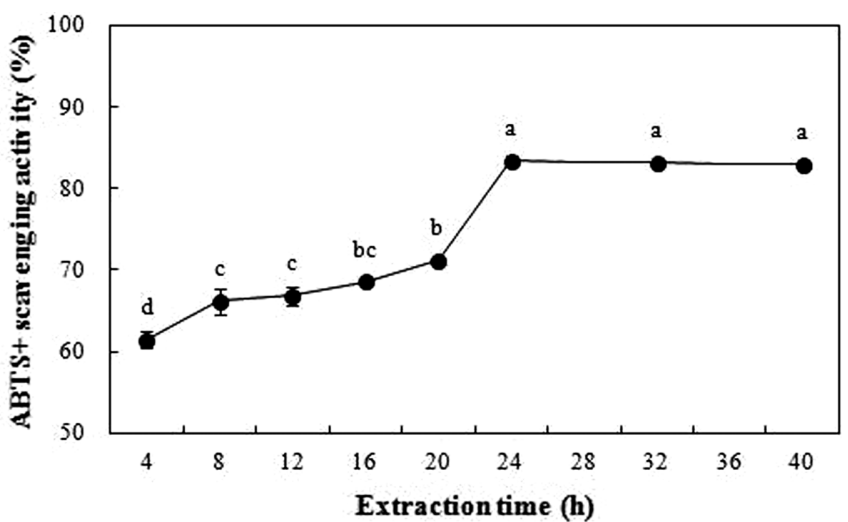

Fig. 4 Changes in antioxidant activity of purple corn cob extract as a function of extraction time. Means with different letters (a-d) are significantly different $(p<0.05)$.

Henry BS (1992) Natural food colors. In Natural Food Colorants, Hendry GAF and Houghton JD (eds), pp.39. Blackie and Son Ltd., Scotland.

Heo HJ and Lee CY (2005) Strawberry and its anthocyanins reduce oxidative stress-induced apoptosis in PC12 cells. J Agric Food Chem 53, 1984-9.

Ichikawa H, Ichiyanagi T, Xu B, Yoshii Y, Nakajima M, and Konishi T (2001) Antioxidant activity of anthocyanin extract from purple black rice. J Medicinal Food 4, 211-8.

Jakobek L, Seruge M, Medvidovic-Kosanovic M, and Novak I (2007) Anthocyanin content and antioxidant activity of various red fruit juices. Deutsche Lebensmittel-Rundschau 103, 58-64.

Jing P and Giusti MM (2007) Effects of extraction conditions on improving the yield and quality of an anthocyanin-rich purple corn (Zea mays L.) color extract. J Food Sci 72, 363-8.

Kenji H, Bayaru E, Hiroki M, and Shigeru S (2009) Silage fermentatice quality and characteristics of anthocyanin stability in anthocyanin-rich corn (Zea mays L.). Asian-Aust J Anim Sci 22, 528-33.

Kim BS, Park YK, and Kang BS (2001) The effect of Rubi fructus on the ovulation and ovary in rats. Kor J Herb 16, 139-52.

Kim JT, Son BY, Lee JS, Baek SB, Kim SL, Kim MJ et al. (2013) National dyeing fabrics with leaf and stem of purple corn. Kor J Crop Sci 58, 113-8.

Lachman J, Hanouz K, Šulc M, Orsák M, Pivec V, Hejtmánková A et al. (2009) Cultivar differences of total anthocyains and anthocyanidins in red and purple fleshed potatoes and their relation to antioxidant activity. Food Chemistry 114, 83643.

Lee HJ, Jang JS, Choi EY, and Kim YH (2008) Anthocyanin content and color stability in black rice according to different extract conditions and selected stabilizers. Kor J Food Nutr 21, 127-34.

Li CY (2007) Antioxidant effect of anthocyanins from purple corn (Zea mays L.) and its application to food. MS thesis, Kangwon National University, Korea.

Lopez-Martinez LX, Oliart-Ros RM, Valerio-Alfaro G, Lee CH, Parkin KL, and Garcia HS (2009) Antioxidant activity, phenolic compounds and anthoctanins content of eighteen strains of Mexican maize. LWT-Food Sci Technol 42, 1187-92.

Malaj N, Simone BCD, Quartarolo AD, and Russo N (2013) 
Spectrophotometric study of the copigmentation of malvidin 3-Oglucoside with p-coumaric, vanillic and syringic acids. Food Chem $\mathbf{1 4 1}$ 3614-20.

Mazza G and Miniati E (1993) In Anthocyanin in fruits, vegetables and grains, CRC Press, UK.

Meiers S, Kemeny M, Weyand U, Gastpar R, Von Angerer E, and Marko D (2001) The anthocyanidins cyanidin and delphinidin are potent inhibitors of the epidermal growth-factor receptor. J Agric Food Chem 49, 958-62.

Mellon JE and Moreau RA (2004) Inhibition of aflatoxin biosynthesis in Aspergillus flavus by diferuloylputrescine and p-coumaroylferuloylputrescine. J Agric Food Chem 52, 6660-3.

Montes C, Vicario IM, Raymundo M, Fett R, and Heredia FJ (2005) Application of tristimulus colourimetry to optimize the extraction of anthocyanin from Jaboticaba (My ricia Jaboricab Berg.). Food Res Int 38, 983-8.

Moyer RA, Hummer KE, Finn CE, Frei B, and Wrolstad RE (2002) Anthocyanins, phenolics and antioxidant capacity in diverse small fruits: vaccinium, rubus, and ribes. J Agric Food Chem 50, 519-25.

Niwa T, Doi U, and Osawa T (2003) Inhibitory activity of cornderived bisamide compounds against $\alpha$-glucosidase. J Agric Food Chem 51, 90 4.

Pavel S, Boøivoj K, and Vlastimil K (2006) Determination of total content of phenolic compounds and their antioxidant activity in vegetablesEvaluation of spectrophotometric methods. J Agric Food Chem 54, 60716.

Plate AYA and Gallaher DD (2005) The potential health benefits of corn components and products. Cereal Foods World 50, 305-14.

Rivero-Prez MD, Muñiz P, and González-Sanjosé ML (2008) Contribution of anthocyanin fraction to the antioxidant properties of wine. Food and Chemical Toxicology 46, 281522.

Seeram NP and Nair MG (2002) Inhibition of lipid peroxidation and structure-activity-related studies of the dietary constituents anthocyanins, anthocyanidins. And catechins. J Agric Food Chem 50, 5308-12.

Smith MA, Rottkamp A, Nunomura A, Raina AK, and Perry G (2000) Oxidative stress in Alzheimer's disease. Biochim Biophys Acta 1502, $139-44$.

Tsuda T, Shiga K, Ohshima K, Kawakishi S, and Osawa T (1996) Inhibition of lipid peroxidation and the active oxygen radical scavenging effect of anthocyanin pigment isolated from Phaseolus Vulgaris L. Biochem Pharmacol 52, 1033-9.

Tsuda T, Watanabe M, Ohshima K, Norinobu S, Choi SW, Kawakishi S et al. (1994) Antioxidative activity of the anthocyanin pigments cyanidin 3-O$\beta$-D-glucoside and cyanidin. J Agric Food Chem 42, 2407-10.

Tusba T, Horio F, Uchida K, Akoi H, and Osawa T (2003) Dietary cyanidin $3-O-\beta$-D-glucoside-rich purple corn color prevents obesity and ameliorates hyperglycemia in mice. J Nutr 133, 2125-35.

Yang Z and Zhai W (2010) Identification and antioxidant activity of anthoctanins extracted from the seed and cob of purple corn (Zea mays L.) Innov Sci Emerg Technol 11, 169-76.

Yang Z, Chen Z, Yuan S, Zhai W, Piao X, and Piao X (2009) Extraction and identification of anthocyanin from purple corn (Zea Mays L.). Int J Food Sci Technol 44, 2485-92. 